\title{
Cornell University
}

\author{
Sergio Preston
}

\section{Writing post-colonial spatial subjects: reading Gorée Island through Frantz Fanon}

\begin{abstract}
:
In Black Skin, White Masks, Frantz Fanon interrogates the role of language in forming the colonial subject, noting that while 'there is an extraordinary power in the possession of a language,' there are also potentially dire side effects, in that a 'man who possesses a language possesses as an indirect consequence the world expressed and implied by this language' (Fanon 2008: 2). This paper assumes that as for the human subject, so too for the spatial subject, as the language used to 'express and imply' the architecture of a place both affects and is affected by colonized subjecthoods and spatial hegemonies. A central aspect of Fanon's project is decolonization of the subject, partly through resistance to the instrumentalization of history, but also through his method of writing, which marshals an interdisciplinarily powerful poetic voice. This essay explores the issue of Fanonian subjectivation as applied to architecture by examining as case study Gorée Island, off the coast of Senegal. Mirroring its turbulent history as a trade hub, competing narratives struggle to take hold of the island. Some such narratives considered here are driven by concern for the island's development (Boubacar Joseph Ndiaye, UNESCO), historical past (Philip Curtin, Mark Hinchman), or its symbolic importance (Dionne Brand). Fanon helps to trace a route through these narratives of Gorée, asking what kinds of writing might perpetuate or resist the colonization of a place, its architecture, and its history.
\end{abstract}

Biographical note:

Sergio Preston has worked as an architect since 2010, and is currently a $\mathrm{PhD}$ candidate in Cornell University's History of Architecture and Urban Development program. His research looks at the ways architecture is implicated in the formation of habit and identity, especially its production and naturalization of sex, gender, race and class.

Keywords:

Creative writing - Frantz Fanon - History - Architecture - Post-Colonialism 
There's so much more to remember, and to describe, for purposes of exorcism, and purposes of celebratory rites of passage. Things must be made. Some fixing ceremony, some altar, some memorial, something, somewhere, where those things can be released, thought, felt. But the consequences of slavery only artists can deal with ... and it's our job!

- Toni Morrison (quoted in Frederickson et al 2013: 221)

There are from one end of the world to the other men who are searching.

I am not a prisoner of History. I must not look for the meaning of my destiny in that direction.

I must constantly remind myself that the real leap consists of introducing invention into life.

In the world I am heading for, I am endlessly creating myself.

- Frantz Fanon, Black Skin, White Masks (Fanon 1952: 204)

\section{Introduction}

Gorée is an island about two miles off the west coast of Dakar, the capital of Senegal. Only nine-hundred metres long and three-hundred metres at its widest point, Gorée has been highly contested as a base of operations for European trade with - and colonization of - Africa. The Portuguese explorer Denis Diaz landed on the island in 1444 - then called Ber by the local Wolof people - and renamed it Palma. In the following centuries it was conquered by the Dutch, reclaimed by the Portuguese, then by the Dutch again, at which point the British took it for a while, until the French were able to retain possession from 1677 until Senegalese independence in 1960. The island's current name - a French corruption of the Dutch Goede Reede, meaning 'good port' (or road) - is just one trace of its history of conflict and commerce.

By some accounts, millions of slaves have passed through the island in preparation for dispersal across the Atlantic. Based largely on this understanding of its role as a major hub in the slave trade, the island was made a UNESCO World Heritage site in 1978, and has acted in that capacity as a backdrop for reflection on the international legacy, complicity, and accountability for slavery. It has become a destination for generations of those left in the wake of African diaspora from which to acknowledge - and attempt to heal - the deep familial rupture that is slavery's inheritance. The island has been visited by dignitaries and celebrities such as Pope John Paul III, US presidents Bill Clinton, George W. Bush, and Barack Obama, Donald Glover, Angela Davis, and Stevie Wonder, to name just a few. Nelson Mandela was reportedly so moved by a tour of Gorée that he wept.

This account of Gorée's historical importance in the trans-atlantic slave trade has since been called into question. The primary source attributing Gorée with having processed millions of slaves was Boubacar Joseph Ndiaye. Chief curator of Gorée Island's Maison des Esclaves (House of Slaves) from 1962 until his death in 2009, Ndiaye gave countless tours of the house, which served as both stage set and historical evidence of an overwhelmingly tragic past. Ndiaye's claims have since been contested, most strongly by Philip Curtin, a scholar of the African slave trade. In his book The Atlantic Slave Trade: A Census (1969), Curtin argues that the number of slaves to pass through Gorée should be counted in the hundreds, rather than millions. Posting on the internet 
listserv Slavery and H-Africa in 1995, Curtin's criticism was even more pointed, calling the Maison des Esclaves a 'hoax' and a 'sham,' more 'an emotional shrine to the slave trade rather than a serious museum' (Curtin 1995). There is a seductive, oppositional symmetry between the figures of Ndiaye and Curtin - heightened further by their having been born and died in the same years (1922-2009) - that parallels the opposing camps who consider the island a shrine or a museum, who come as pilgrims or as historians.

These competing narratives of Gorée first reached international attention when Le Monde published a summary of Curtin's criticisms in 1996 (De Roux 1996), which in turn inspired a response in the form of a conference on Gorée in 1997. According to Ralph Austen, the moral dimension underlying production of any history of the slave trade tended, on this issue, 'to create a divide between white and black historians,' and '[d]espite claims by Curtin and even his critics in the Gorée dispute, there is a persistent sense that to lower earlier estimates of the number of victims is to diminish the level and significance of the suffering' (Austen 2001: 236-7). Recognizing that Ndiaye was not a scholar, nor had he ever produced documentary evidence to support his tabulations, Austen suggests that Ndiaye may have been less motivated by exact numbers than a desire to communicate the very high number of people victimized by slavery, and the incalculable suffering which it was responsible for producing. Ndiaye used the Maison des Esclaves to locate a narrative not only of the verifiable slave traffic through Gorée, but perhaps to acknowledge the whole atrocity of the Middle Passage. Before historical scholarship on the area had begun in earnest, Ndiaye could present his 'millions' without fear of contradiction. While he may have felt differently had Ndiaye explicitly framed the Maison as an 'emotional shrine' from the beginning, Curtin seems to have indicated with the appellations 'sham' and 'hoax' a rejection of Ndiaye's entire project.

Amidst these myriad efforts of reckoning with what Gorée Island was, this essay instead takes on the question of what Gorée Island now is, and what it might be: how do these conflicting narratives continue to produce such seemingly irreconcilable versions of the same stubbornly material stretch of sand? On one hand, Ndiaye's account of Gorée as a hugely important slave hub has garnered international attention, infused the island with extraordinary architectural significance, and facilitated the economic, material, and political aggregation necessary to turn it into an international site of pilgrimage for the African diaspora. On Curtin's side, however, Ndiaye's failure to ground such narratives in what might be considered historical evidence allows the whole enterprise to be dismissed as a hoax. While I believe Ndiaye's intent and results to have been largely positive, I recognize that his methods were problematic. I am interested in thinking through the complexities of the writing of the island especially through Frantz Fanon's pivotal book, Black Skin, White Masks, and asking if these various narratives might supplant or provide opportunity for expansion of his particular notions of resistance against colonizing histories. Fanon, I think, offers a method of narrativizing Gorée as an architectural subject that reimagines the conflictual divisions at play here between memory and history, between moral emotionality and numerical accuracy, between shrine and museum.

I will primarily focus the analysis on three diverse but sometimes overlapping versions of Gorée: those by Ndiaye, UNESCO, and Dionne Brand. These three provide the groundwork from which to both provide additional context on Gorée and through which to trace a potentially distinct reading offered by Fanon's Black Skin, White Masks. 


\section{Frantz Fanon and Black Skin, White Masks}

Given its centrality to this investigation, an explanation of how I see Fanon contributing methodologically to this project seems relevant, especially given that he makes no explicit reference in Black Skin, White Masks to architecture, nor to Gorée, nor in fact does he write of history except from a position of repudiation. How, then, is this a useful place from which to engage with Gorée Island as a spatial, architectural, or historical subject?

Black Skin, White Masks is Fanon's autobiographical, philosophical, poetic, psychoanalytic diagnosis of the role of language, history, and narrative in the entrapment of colonized subjects within systems of colonial oppression. Born in the French colony of Martinique in 1952, Fanon had first-hand experience of how the resiliency of such systems is based on their simultaneous deployment along a variety of registers: for example spatial, temporal, and verbal. He traces how colonial narratives are transmitted by language into the psychology of colonized subjects, becoming a kind of sociopathy. 'A man who possesses a language,' he writes, 'possesses as an indirect consequence the world expressed and implied by this language.' Working from his own experience, he describes how black colonized subjects internalize structures of power transmitted by the language of white colonizers. Such language demeans blackness and associates only whiteness with humanity, such that 'the more the black Antillean assimilates the French language, the whiter he gets - i.e., the closer he [believes he] comes to becoming a true human being' (Fanon 1952: 2). Fanon frequently puts himself under examination, analyzing his own confrontations with colonialism, conveying how structures of oppression come to adhere to his skin, and even more specifically, his skin color. He describes the trauma of being a black body in societies that work to flatten his sense of self - his body schema - to simply the color of his skin. In one instance, Fanon describes how what was a 'body schema was now a historical-racial schema,' woven by 'the Other, the white man... out of a thousand details, anecdotes, and stories' (Fanon: 91). As a result, 'the body schema, attacked in several places, collapsed, giving way to an epidermal racial schema.' While he wants 'quite simply to be a man among men,' this process of epidermalization makes him simultaneously 'responsible not only for [his] body but also for [his] race and [his] ancestors' (92). Fanon resists this association, trying to argue an alternative in which his 'black skin is not a repository for specific values' (202), not beholden to any history, its ownership restored to himself.

While Fanon writes explicitly neither about architecture nor about Gorée Island, his description of various narratives being affixed to his skin for the sake of perpetuating colonialist systems of oppression has relevance to architectural writing. Edward Said (neatly paraphrasing Gaston Bachelard) writes about a similar condition, describing how space 'acquires a sense of intimacy, secrecy, security, real or imagined, because of the experiences that come to seem appropriate for it.' In a process seemingly akin to epidermalization, he writes that the 'objective space of a house - its corners, corridors, cellar, rooms - is far less important than what poetically it is endowed with, which is usually a quality with an imaginative or figurative value we can name and feel: thus a house may be haunted, or homelike, or prisonlike, or magical' (Said 1978: 54-55). The experience of these spaces, or of Fanon himself, have less to do with their actual qualities than with their associated narratives.

Gorée Island and the Maison des Esclaves offer a rich case study of a space being torn between simultaneous, competing narratives: between home or prison, haunted or magical, 'emotional shrine' or 'real museum.' In the way Fanon writes about escaping 
or mitigating the colonization of black bodies, does he also offer a method of escaping colonialism in writing about architecture, by making neither merely repositories for specific values?

\section{Returning to Gorée}

Although the Maison des Esclaves acquired that name prior to the start of his conservatorship in 1962, no one is more responsible for its international dissemination and its associated narratives than Boubacar Joseph Ndiaye. The Maison is Gorée's most famous house, and indicative of many typological features common to the island. It is double storied with covered galleries and an aura of hospitable welcome on the side of the interior courtyard. The rear, though, is a fortified wall punctured only by arrow slits and a gallery without access to the ground floor, all turned toward the wild expanse of ocean. The Maison's most striking feature are the double, rococo flavoured, curved staircases in the courtyard. Originally built for a single, slave owning family, the stairs provide all the vertical access for the house, which would have been used by all. The stairs also frame the building's central axis, whose full mass is pierced on the ground floor by a long hallway terminating dramatically at the fortified ocean face. That final door, opening onto a slim, rocky, strip between wall and water, has come to be known as the Door of No Return.

The spatial characteristics of the Maison seemed perfectly designed for the acts of violence to which Ndiaye attributed them, and '[b]y the 1990s', writes architectural historian Mark Hinchman, Ndiaye's 'tour of the house had become a well honed performance' (Hinchman 2015: 309). According to Ndiaye, the central courtyard was a place used to welcome slave traders, the stairs and upper galleries acted as stages on which to display the slaves' bodies. On the ground floor were small rooms, cells in which to hold 'slaves and separated men, women, boys, girls, and recalcitrants' (Hinchman 2015: 309). Some of these rooms had chains attached to the walls, offering for Ndiaye proof of slavery, and an opportunity to end his tours with a flourish. 'He lifted a set of chains into the air and rhetorically asked how the slave trade could have happened. Many photographs show Ndiaye in this dramatic position' (Hinchman 2015: 309). Primed by this narrative, it takes no effort of imagination to sense malicious intent in the stark act of passing from the bright courtyard, under the mandorla sweep of the stairs, into the long dark passage, ending with abrupt finality on the rocky shore, and the Atlantic's endless water. The fact that this passage is on the Maison des Esclaves' central axis suggests that whatever its purpose, given its spatial, hierarchical primacy, it is one around which the entire house had been organized. Each of these spatial features lent Ndiaye's narrative power and credibility, made the whole house seem directed toward the keeping, presentation, and eventual distribution of human bodies. In the process described by Said above, slavery is made to seem the experience most appropriate to the Maison's spaces.

Curtin's rejection of Ndiaye's numbers undermines the likelihood of these suggested uses. Hinchman also provides quite a different story of the house, beginning with the name. Instead of the historically contested Maison des Esclaves, he refers to the house as 'the Maison Pépin, in order to emphasize its early life as a functioning household' and to connect it to its first owner, Anne Pépin (Hinchman 2015: 89). The small cells on the ground floor Hinchman attributes to the mundane requirements of household storage and operation. That some of these rooms included chains suggests to Hinchman that they may have at one time been used as a prison, as other houses on the island had 
been. According to some accounts given by the Associated Press, the door itself, sinister symbol of Diaspora, 'faced the ocean so that the inhabitants of the house could chuck their garbage into the water' (Fisher 2013). Wildly different narratives are seen here affixing themselves to the same architectural properties: a prison becomes a dimly lit pantry; the poignant image of President Obama - the first African-American President - standing at the Door of No Return, gazing somberly from one of the greatest symbols of slavery's tragedy across the Middle Passage, suddenly has him blocking a trash chute.

\section{UNESCO's Gorée Island}

Gorée Island was designated a UNESCO World Heritage Site in 1978. UNESCO's version of Gorée seems to balance itself diplomatically between these contrary narratives, occupying a position somewhere between 'emotional shrine' and 'serious museum.' They begin, anyway, by building on Ndiaye's spatialized history, disseminating those narratives internationally and using it as justification for material alterations to the island itself. Gorée: Island of Memories was written by a committee of UNESCO associates, producing a booklet that 'appeals to our memories and calls on each of us to help to safeguard Gorée' (UNESCO 1985: Preface). The booklet describes Gorée as 'a happy symbiosis of past and present, history and everyday life, the harmony of visual forms and the dramatic imprint of bygone days.' Although never contradicting Ndiaye's presentation of the island as a major slave hub, there is something of a tourism brochure in reducing Gorée's supposed inextricable involvement in slavery to a 'dramatic imprint,' and setting that beside its harmonic visual form. The intention to memorialize the island as a site for Diaspora pilgrimage is explicity intended to make it 'one of those rare places where the younger generation of Africa and the Americas can refresh their memories while at the same time renewing the sources of their inspiration.' The UNESCO booklet further enhances the island as an international memorial, belonging 'to the living imagination of Africa and the Americas... [but] in equal measure to the minds of men the world over' (UNESCO 1985: 12). The booklet's associated revitalization plan attempts mainly to develop Gorée as an international cultural centre by raising funds to provide infrastructure for hosting conferences on the history of slavery, an International Festival of Negro Arts, cultural tours, and educational facilities.

In order to do so, UNESCO proposes that Gorée be architecturally converted to better accord with its presentation as an historic location. One such action focused on existing buildings, calling for 'removal of additions and accretions; restoration of period facades; consolidation; re-opening of bricked-up doors and windows; reconstruction of missing parts, and so forth' (UNESCO 1985: 48). It also calls for the modernization of Gorée's infrastructure and museums, including the Maison des Esclaves, in order to better accommodate international tourism. In a recursive process, the story told here about the island is instrumentalized to secure funds which were then used to make the island better conform materially and spatially to the initial narrative.

What might Fanon think of UNESCO's treatment of Gorée? On the one hand, Fanon often displays an antagonism to history, writing that disalienation will be only for those that "have refused to let themselves be locked in the substantialized "tower of the past.", An aspect of this antagonism is the ascription of history along racial lines. 'In no way,' writes Fanon, 'do I have to dedicate myself to reviving a black civilization justly ignored. I will not make myself the man of any past. I do not want to sing the past to 
the detriment of my present and my future' (Fanon: 201). All participants in colonial systems are trapped by them, even those who ostensibly benefit. Fanon's goal is not to elevate a specifically 'black history' to a level equal with 'white history,' as that would only attempt - to borrow a phrase from Audre Lorde - to dismantle the master's house with the master's tools. He denies the very premise of histories as racial inheritance, instead he 'reach[es] out for the universal' (Fanon: 174), for history as a shared human condition in which 'the Peloponnesian War is as much mine as the invention of the compass' (Fanon: 205). His interest in a shared, human, universal history is not to suggest a lack of interest in black cultural achievements, however:

Above all, let there be no misunderstanding. We are convinced that it would
be of enormous interest to discover a black literature or architecture from the
third century before Christ. We would be overjoyed to learn of the existence
of a correspondence between some black philosopher and Plato. But we can
absolutely not see how this fact would change the lives of eight-year-old kids
working in the cane fields of Martinique or Guadeloupe. (Fanon: 205)

This is a theme that Fanon approaches often, from various angles. A milder reading might suggest that it is not history itself against which Fanon pushes, but a particular kind of historicity, one whose preoccupation with the past is used to obscure problems of the present. A form of instrumentalized history used as justification for the continued performance of colonial oppressions, and treated as teleological determination of future adherence to such systems.

In this light, UNESCO's formulation of Goree as a historical subject suggests split criteria. Building on Ndiaye, UNESCO certainly instrumentalizes a particular version of the past, even further locking the island into this narrative by making it the basis for economic, infrastructural, and cultural reinvention. Re-purposing the island's architecture so that it conforms to that mythologized historical image is perhaps the clearest indication of this, as though under the presumption of disalienation UNESCO has merely renovated, rather than escaped, the tower of the past.

Establishing Gorée as a World Heritage Site can be seen as an improvement in some considerable ways. It was an opportunity to attract significant funds to Gorée, locally redressing residual effects of African colonization. At the time the UNESCO booklet was written, the island was home to only 1,000 residents, as compared to 5,000 at its prime. While not directly aimed at the worst instances of current manifestations of colonialism - the plight of, for example, eight-year-old cane farmers - the importance of the island's economic revitalization is not to be entirely dismissed. Fanon recognizes the considerable role of economics in the perpetuation of colonialism, writing that 'the true disalienation of the black man implies a brutal awareness of the social and economic realities' (Fanon: xiv). Addressing the role of economics does not necessarily call for an economic solution, however. Sylvia Wynter, for example, builds on Fanon to argue that the economic enfranchisement of the economically marginalized does not accomplish Fanon's larger project. In her reading, colonialism and capitalism are both symptoms of the same cultural condition (Wynter 2006) so to seek escape from colonialism through economic instead of more significant cultural reform merely reifies the underlying problem.

UNESCO's reinforcement of Ndiaye's version of Gorée also seems to set the conditions for two of the most vital aspects of Fanon's project: recognition and action. 'I am fighting,' writes Fanon, 'for the birth of a human world, in other words, a world of reciprocal recognitions' (Fanon: 193). Recognition, simple recognition, is the universal 
condition obscured by the process of epidermalization for which Fanon was reaching. In the highly affecting narratives by which Gorée is made a site of extreme importance to the slave trade, there is a unique opportunity for recognition of the legacy of the Diaspora. The large numbers of pilgrims to the Maison des Esclaves - including those like Nelson Mandela moved to the point of intense emotion - are testament to its efficacy in providing a stage for recognizing on a personal level the plight of the enslaved. While these visitors are a self-selecting group already interested in experiencing such recognition, international dissemination of such narratives, by whatever means possible, is presumably an important aspect of colonial resistance.

Recognition, while an important start, is not the end, as Fanon also attempts to 'induce man to be actional, by maintaining in his circularity the respect of the fundamental values that make the world human, that is the task of utmost urgency' (Fanon: 197) Without action, recognition is empty. With its various cultural institutions and financial infrastructure, Gorée is also uniquely prepared to act against colonial narratives. Being made a UNESCO site in 1978 provided Goree with a new degree of cultural clout. Having built through that process a degree of international recognition, Gorée was able to host a conference in 1997, a year after the critical piece was run in Le Monde diminishing its importance. It was able to quickly organize a conference defending itself as a center for post-colonial action.

It may be that the price of instrumentalized history for the sake of these scenes of recognition and action is too high to warrant their use, that Ndiaye and UNESCO's Gorée may ultimately only further the entrenchment of colonial narratives, by reifying the underlying material, economic, and knowledge structures. This seems particularly true given that, by appealing to historical accuracy, which has since come into question, Ndiaye has positioned that narrative of the island to lose credibility. It bears repeating that scholars on both sides agree that recognition of the suffering caused by slavery and Gorée's even oblique complicity in it - should not be dependent only on a higher number of slaves having been moved through there. Yet, to have recreated Gorée as an important site of post-colonial community based on a seeming fabrication undermines its value and efficacy. Might this be partly why Fanon does not found his project of decolonization on history at all? Is it an inevitable vulnerability of history to be always rewritten, reimagined, repurposed, re-colonized? Is history the wrong terrain entirely on which to attempt to build disalienation? Is this why Fanon writes that 'it is [only] by going beyond the historical and instrumental given that I initiate my cycle of freedom' (Fanon: 205)? How might reciprocal recognition and its subsequent actional requirements be kept, while removing the historical and instrumental? How might a version of Gorée be written that, rather than instrumentalizing the past, focuses on an open and disalienating future?

\section{Dionne Brand}

Dionne Brand provides a useful counterpoint to the UNESCO booklet. In The Door of No Return, she shares with Fanon a poetic, autobiographical method of writing, one that begins with her as a child asking her grandfather for the name of the people from which they had come: 'Yoruba? Ibo? Ashanti? Mandingo?' (Brand 2001: 3). Because he could not answer, a space opened inside her that became 'a rupture in history, a rupture in the quality of being. It was also a physical rupture, a rupture of geography.' For Brand, 'having no name to call on was having no past; having no past pointed to the fissure between the past and the present' (Brand 2001: 5). This fissure, this vacuum 
in her history, this rupture in history and geography, has a point of origin. This is the place she calls the Door of No Return, a place for Brand geographically 'at slave castles in Ghana or Gorée Island,' but as much a conceptual place as physical. More a blade than a doorway, the Door severed those who passed through it from their histories, from their people, from the names of their people, from their own names, making it an obscene 'creation place... a place emptied of beginnings... a site of belonging or unbelonging' (Brand 2001: 6). Far from UNESCO's 'happy symbiosis of past and present,' at the core of Brand's Gorée is an unattainable origin, an impossibility of return.

Perhaps due partly to the perspective gained from having written her book after the Le Monde controversy, Brand claims the emotionally recuperative qualities of Gorée without relying heavily on historical accuracy. This is a stance that seems to have recent, widespread adoption. For example, a plate placed in 1999 near the House of Slaves has an inscription of a text by Jean-Louis Roy:

Celui qui vou a dit 'Gorée est une île' / Celui-là a menti / Cette île n'est pas une île / Elle est continent de l'esprit

[The one who says to you 'Gorée is an island' / This one has lied / This island is not an island / It is a continent of the spirit]

Narrativizing Gorée in this way, less as an actual landmass than a spiritual condition, positions the island unapologetically in the 'emotional shrine' camp. Author Maya Angelou also develops this theme, saying that on her visit to Gorée '[w]e had come home, and if home was not what we had expected, never mind, our need for belonging allowed us to ignore the obvious and create real places or even illusory places, befitting our imagination' (quoted in Abaka 2012: 348). She commits fully to the place as potentially illusory, or imaginary, expressing that Gorée and the Maison des Esclaves need not be spatially real for them to serve a redemptive purpose, the need for belonging was enough to warrant an attachment to that place as a surrogate home even while ignoring those qualities which defied expectation or facticity. A need for the unknowable island behind its narrative masks made the specific features of those masks shrink in importance.

Not only is Brand unconcerned with the role of historical validity in constituting the island's redemptive qualities, but she expresses mistrust at attempts to assign historical or geographic origins, writing that while potentially nourishing, origins are arbitrary, and 'essentially coercive and indifferent' (Brand 2001: 64). Although writing here specifically about the strategic role of designating a class of people as 'immigrant' in her home country of Canada, she is also offering a potent parallel reflection on her approach to the Door of No Return, and a relation to personal history.

Too much has been made of origins. And so if I reject this notion of origins I have also rejected its mirror, which is the sense of origins used by the powerless to contest power in a society... These are mirror/image image/mirror of each other and are inevitably conservative. Because they must draw very definite borders both to contain their constituencies as well as, in the case of the powerful, to aggressively exclude the other and, in the case of the powerless, to weakly do the same while waving a white flag to the powerful for inclusion. Each of these arguments select and calcify origins. Out of a multiplicity of stories, they cobble together a narrative glossing over accident, opportunism, necessity, and misdirection. (Brand 2001: 69-70)

What Brand offers in this paragraph is an expansion of the danger of the rhetoric of origins in ways that echo Fanon's resistance to history. Brand recognizes that 
organization around shared origin is a method of defining constituency. From that position, the powerless are able to contest social power from which they are excluded, or by which they are oppressed. This strategy, though, is inherently conservative, as it uses the same methods as the powerful. In doing so, the powerless validate the systems utilized by the powerful in their own exclusion, placing the powerless inevitably, and permanently, in a weaker position, leaving them recourse only by way of weakly 'waving a white flag to the powerful for inclusion.' The tacit sanctioning of these systems of power ossifies the powerless within those systems, leaving them obliged, in Fanon's words, 'to sing the past to the detriment of [their] present and [their] future' (Fanon: 201). By making its historical significance the linchpin of Gorée's cultural importance, Ndiaye appeals for its inclusion in existing systems of power. Invalidation of its historical claims then undermines its symbolic and architectural value as a site from which to memorialize the history of slavery, much less from which to stage the writing of decolonized futures.

What is lost by making such appeals to existing structures of power, Brand suggests, are the greatest tools of the powerless: their multiplicity of stories, the accidental, their opportunisms and misdirections. Tidiness, as a quality of historical narrative, is already a colonizer's tool, reducing dynamic, complex totalities into easy categories of race, origin, or history. This attempt to rupture subjects from the messy, three-dimensionality of their experience causes, according to Fanon, the intellectual alienation that is endemic of bourgeois society, and a central aspect of colonized narratives.

And for me bourgeois society is any society that becomes ossified in a predetermined mold, stifling any development, progress, or discovery. For me bourgeois society is a closed society where it's not good to be alive, where the air is rotten and ideas and people are putrefying. And I believe that a man who takes a stand against this living death is in a way a revolutionary. (Fanon: 199)

Brand writes herself through a similar problem. She begins by searching for the name of her people, and a sense of origin with which to heal her future. But when she arrives at the place where those things are meant to be, it is not there. Arriving at the Maison des Esclaves, finally reaching her destination at the Door of No Return, all she offers is a dull list of features, a series of lines standing alone, cold descriptions that echo Ndiaye's narrativizations of the building (Brand 2001: 174). This, I think, is inevitable. She began with a question, and an answer, for a question, is a death wish. What Brand starts off asking for from the Door of No Return is the impossibility of an arrival at an alternate past, but all she finds is a building. It was the question, though, the constant opening into an indeterminate future, that Fanon was pointing to, and with which he ends Black Skin, White Masks: 'My final prayer: / O my body, always make me a man who questions!' (Fanon: 206).

\section{Ways of writing}

While there are other vocabularies for describing the means by which varying narratives attach themselves to space, Frantz Fanon's Black Skin, White Masks gives language a different degree of importance and urgency. For Fanon, language is a force capable of reorganizing both material and subjective orders, for embroiling subjects in systems of oppression, and for conditioning desires. Expanding compellingly on Fanon's hypothesis, Sylvia Wynter argues that black skins wearing white masks is just 'a special case of the fact that all humans wear cultural masks,' so that 
although born as biological humans (as human skins), we can experience ourselves as human only through the mediation of processes of socialization effected by invented tekhne or cultural technology to which we give the name culture. (Wynter 2001: 53)

While she considers language the primary cultural technology, the example of Gorée shows how the affects of language may be further bolstered by attachment to spaces. Architecture gives Ndiaye's narrative a degree of timelessness and inevitability, loaning it material credibility. Given this amplification, it seems particularly important when writing on architecture to avoid perpetuating colonial systems.

Many of Fanon's strategies for resisting colonialism have been explored already: a repudiation of the historical in order to preference the present and future; attention paid to the actional, with aspirations to mutual recognition; the living, messy, multivalence of questions rather than the putrefied, bourgeoisie, tidiness of answers. These strategies, or their absence, manifest themselves as much in the styles of writing as in their content. Fanon's writing itself is a useful example, for although Black Skin, White Masks was published in 1952, Fanon began writing it in 1949 as his dissertation for medical school. It was rejected, as the medical faculty who reviewed it considered Fanon's incorporation of his own subjective conscious reactions to be invalidating (Ehlen 2008: 97-98). In order for writing to even attempt mutual recognition, the author as subject can not be obscured. Fanon, Brand - and to an extent, Ndiaye - present narratives that centralize human subjects, sometimes including themselves. Fanon is the figure reaching through the page, past the mask of his own writing, for recognition. The motivations of his writing are transparent, the stakes are pressing and evident. His writing is not confined by discipline, moving between analysis, philosophy, autobiography, and poetry in order to make the full scope of his project accessible. He does not write as a committee, nor does he retreat to the presumed objectivity of a distant, historical voice. If Fanon's writing lives, it does so not because it attempts timelessness, but because of its immediacy. If Fanon's writing leaps, it is because it introduces invention, creating a voice all its own, and for itself. Fanon's style of writing, or the attempt behind it to draw the reader into poetic rapport as a form of mutual recognition, seems as important an aspect of his project of post-colonialism as any particular part of its content.

\section{Conclusion}

This essay has explored the controversy surrounding Gorée Island resulting from two primary but competing narratives describing its role in the slave trade. One version is by Joseph Ndiaye, who built a career on saying it was a base of operations which processed millions of slaves. The other narrative is represented here mainly by Philip Curtin, who counts that number instead in the hundreds. The discrepancies between these two narratives are not mere games of language, but have real material effects and the potential to alter the subjective experience of those who engage with the site. For example, on the basis of Ndiaye's narrative, Gorée has been recognized as a UNESCO World Heritage site, and its subsequent development - along lines that make it formally adhere more closely to that same historical narrative - has allowed it to become a destination for Diaspora tourism, activism, and reflection.

The discrepancy is particularly pronounced in the figure of the Maison des Esclaves. For Ndiaye, the entirety of the space takes on sinister association in its role in the preparation of slaves for journey through the Middle Passage. In more strictly, discursively, historical accounts, however, the same spaces instead become a record of 
quotidian life: the infamous Door of No Return becomes nothing more than a means of depositing trash into the ocean. The variability between these narratives and their application to the Maison is reminiscent of Fanon's concept of epidermalization, by which his skin (color) - despite himself - is made a repository for a variety of narratives, values and histories. Fanon objects particularly to histories, since by attaching a particular origin, history becomes a means of teleologically determining the potentiality of a subject's futures. Here I see room - via Brand - for a critique of Ndiaye's narrativization of the island, in that by founding a call for recognition of Gorée on its supposed historical value, he draws it into established systems of power, knowledge, and capital that ultimately reinforce rather than rectify the colonial imbalance.

If space is affected by the narratives associated with it in ways similar to the human subject described by Fanon, the means in which space is written becomes increasingly important as a site from which to resist the systems of oppression inherited through language. In this, Fanon and Brand offer examples by resisting the coloniality of the page. A chief means of Fanon's resistance to colonization seeks mutual recognition of the subject through, and perhaps despite, the sorts of narrative masks that all skin and space is made to wear. Such resistance, I argue, happens also in the space of writing, and of writing about architecture. Fanon's written voice is disciplinarily undefinable, weaving poetically through a wide variety of discursive methodologies. With mutual recognition as its goal, both he and Brand present themselves within their writing as subjects. Brand does this even more explicity, describing her arrival at the Door of No Return subjectively, the spatial characteristics almost secondary to its existence as a narrative subject. This points toward, if not a precise methodology for a means of writing spatial subjects resistant to colonial systems, at least a beginning ground untidy and multivalent - from which to attempt a leap.

\section{Works cited}

Abaka, Edmund Kobina 2012 House of Slaves and 'Door of No Return': Gold Coast/Ghana Slave Forts, Castles \& Dungeons and the Atlantic Slave Trade, Trenton NJ: Africa World Press

Austen, Ralph A. 2001 'The Slave Trade as History and Memory: Confrontations of Slaving Voyage Documents and Communal Traditions', The William and Mary Quarterly 58 (1) January, 229

Brand, Dionne 2001 A Map to the Door of No Return : Notes to Belonging, Toronto: Doubleday Canada

Curtin, Philip D 1969 The Atlantic Slave Trade: A Census, Madison: University of Wisconsin Press 1995 'Gorée and the Atlantic Slave Trade | H-Africa | H-Net', https://networks.hnet.org/node/28765/pages/31923/goree-and-atlantic-slave-trade

De Roux, Emmanuel 1996 'Le mythe de la Maison des esclaves qui résiste à la réalité', Le Monde Ehlen, Patrick 2008 Frantz Fanon: A Spiritual Biography, New York: Crossroad Fanon, Frantz 1952 (ed. 2008) Black Skin, White Masks, New York: Grove Press

Fisher, Max 2013 'What Obama Really Saw at the "Door of No Return," a Disputed Memorial to the Slave Trade; Scholars Concluded 20 Years Ago That the Site Was Not Really so Important for the Slave Trade, but It Still Matters', The Washington Post

Frederickson, Mary E., and Delores M. Walters (eds) 2013 Gendered Resistance: Women, Slavery, and the Legacy of Margaret Garner, Urbana: University of Illinois Press 
Hinchman, Mark 2015 Portrait of an Island: The Architecture and Material Culture of Gorée, Sénégal, 1758-1837, Lincoln: University of Nebraska Press

Said, Edward W., 1978 Orientalism, New York: Pantheon Books

UNESCO 1985 Gorée, Island of Memories, Paris: UNESCO

Wynter, Sylvia 2006 'On How We Mistook the Map for the Territory, and Re-Imprisoned Ourselves in Our Unbearble Wrongness of Being, of Désêtre: Black Studies Toward the Human Project', in Not Only the Master's Tools: African-American Studies in Theory and Practice, Boulder: Paradigm: 10769

2001 'Towards the Sociogenic Principle: Fanon, Identity, and the Puzzle of Conscious Experience, and What It Is Like to Be "Black", in National Identities and Sociopolitical Changes in Latin America, New York: Routledge 23:30-66 